\title{
Przejście od klimatu przemocy do przemocy konkretnej. Kategoria rewolucji w filozofii Frantza Fanona
}

\section{Izabela PoręBA}

\begin{abstract}
Streszczenie
Artykuł stanowi omówienie filozoficznej koncepcji rewolucji Frantza Fanona sformułowanej w odniesieniu do procesu dekolonizacji w $W y$ klętym ludzie ziemi. Szczegółowo przeanalizowana została koncepcja „podzielonego świata”, wedle której rzeczywistość kolonialna stanowi dwudzielną, niekoherentną przestrzeń wymuszonej koegzystencji skolonizowanego i kolonizatora. Animalistyczna, deprymująca ludność natywną, metaforyka wykorzystywana dla opisu podległej przestrzeni jest sposobem na umocnienie różnicy i podkreślenie odrębności (nie tylko kulturowej, lecz także rasowej, a nawet wprowadzenia opozycji ludzkie - nieludzkie/zwierzęce). W ramach prorewolucyjnego stanowiska Fanona ocena przemocy i walki narodowowyzwoleńczej zostaje zawieszona lub zrelatywizowana. Nieodłączność przemocy i zagrożenia, jakie niosły ze sobą formy oporu oraz moment przejścia od pierwszych, łagodnych strategii buntu po rewolucyjne ruchy prowadzące do dekolonizacji są kolejnymi przedmiotami refleksji. W ostatniej części artykułu przedstawione zostały nawiązania do filozoficznej koncepcji Fanona.
\end{abstract}

Słowa kluczowe: kolonializm, Frantz Fanon, rewolucja, przemoc, dekolonizacja

Izabela PoRĘBA magister filologii polskiej oraz publikowania cyfrowego i sieciowego, doktorantka na Wydziale Filologicznym Uniwersytetu Wrocławskiego. Pisze rozprawę doktorską pod kierunkiem dra hab. prof. UWr Mariana Bieleckiego na temat postkolonialnych strategii pisania twórców tzw. frankofońskiej literatury afrykańskiej. Interesuje się przede wszystkim kulturową teorią badań literackich, postkolonializmem, literaturą światową i filozofią.

E-MAIL: izabela.poreba@uwr.edu.pl 
W pracach Frantza Fanona zarysowuje się wyraźnie koncepcja rewolucji i jej szczególne znaczenie dla skolonizowanych krajów afrykańskich. Wyłożona w Wyklętym ludzie ziemi teoria ruchu rewolucyjnego i refleksja nad kondycją skolonizowanego i kolonizatora stanowi z perspektywy historycznej jedną z prac inicjujących badania nad nacjonalizmem krajów „Trzeciego Świata” oraz studia postkolonialne (Rajeev 2001, 162). Założycielska rozprawa postkolonializmu jest wciąż żywą tradycją tych badań: znajduje ważne miejsce $\mathrm{w}$ pracach pochodzących jeszcze $\mathrm{z}$ lat siedemdziesiątych XX wieku (Edwarda W. Saida), najważniejszych rozprawach z ostatniej dekady ubiegłego wieku (Homiego K. Bhabhy, Saida) oraz we współczesnych badaniach (Achillego Mbembego, Reilanda Rabaki). Jego myśli są istotne nie tylko ze względu na wnikliwą rejestrację pewnego historycznego momentu z jego konsekwencjami psychoemocjonalnymi dla ludności w trakcie dekolonizacji, lecz także przez wzgląd na diagnozę zagrożeń pojawiających się w czasie powstania i jego nieomal wieszcze przewidywania problemów, jakie mogą stać się udziałem nowo wyzwolonych państw afrykańskich.

Frantz Fanon urodził się na Martynice francuskiej 20 lipca 1925 roku i dorastał w warunkach kolonialnej kultury. Dwa lata walczył po stronie francuskiej w czasie drugiej wojny światowej, co umożliwiło mu podjęcie studiów medycznych i psychiatrycznych na Uniwersytecie w Lyonie. Praktyce lekarskiej towarzyszyło poczucie wyizolowania i odrębności - jako czarnoskórego lekarza we Francji, spotykającego się z brakiem zaufania i przejawami rasizmu, czemu poświęcił swoją pierwszą książkę Peau noire, masques blancs (1952; polskie wydanie: Czarna skóra, białe maski, tłum. Urszula Kropiwiec, Karakter, Kraków 2020). W 1953 roku objął z ramienia francuskiego rządu funkcję dyrektora jedynego w ówczesnych czasach szpitala psychiatrycznego w Algierii - w leżącej poza metropolią Blidzie. Pracę naukową i lekarską kontynuował jeszcze przez dwa lata po wybuchu powstania w Algierii, do 1956 roku, kiedy zrezygnował z działania na rzecz francuskiego rządu, został wyeksmitowany z Algierii i przyłączył się do rewolucyjnych ruchów narodowowyzwoleńczych. Nadal pracował jako lekarz, przeniesiony do tunezyjskiej Manuby. Badał w szczególności zaburzenia psychiczne wywołane kolonialną przemocą oraz udziałem w partyzanckich walkach. Ponadto zajmował się działalnością informacyjną w podziemnym czasopiśmie rewolucyjnym „El-Moudjahid”.

W końcu - w czasie nasilenia powstania i umiędzynarodowiania algierskiego konfliktu - Fanon porzucił praktykę psychiatryczną i stał się rzecznikiem Rządu Tymczasowego. Nawiązał kontakt z przywódcami państw 
afrykańskich, którym wskazywał kierunek przeobrażeń społecznych kolonii, oczekując gestów poparcia dla algierskiej rewolucji, działał na rzecz utworzenia Front de Libération Nationale (Frontu Wyzwolenia Narodowego) na malijskiej granicy. W 1961 roku - świadomy zbliżającej się śmierci z powodu białaczki - Fanon napisał trzecią, i ostatnią, książkę Les damnes de la terre (polskie wydanie: Fanon 1985), stanowiącą najpełniejszy wykład jego poglądów na powstanie w Algierii, pojęcie narodu i przemocy w sytuacji rewolucyjnej. Wydano ponadto dwa zbiory esejów napisanych przez Fanona: L'An $V$ de la revolution algérienne (1959; polskie wydanie: Algieria zrzuca zastonę, tłum. Zygmunt Szymański, Iskry, Warszawa 1962) i Pour la revolution africaine. Écrits politiques (1964). Początkowo Fanon leczył się w Moskwie, zmarł w szpitalu w Stanach Zjednoczonych 6 grudnia 1961 roku w wieku trzydziestu sześciu lat.

Przedmiotem szkicu jest przedstawienie Fanonowskiej koncepcji rewolucji i wskazanie jej kontynuatorów wśród myślicieli postkolonializmu. Kluczowe elementy dekolonizacji widzianej jako konieczność walki o wyzwolenie zostały ujęte w kolejnych częściach artykułu. Rozważaniom poddane zostały więc zagadnienie etycznej odpowiedzialności buntownika za przemoc dokonywaną w imię rewolucji oraz Fanonowska koncepcja przebiegu i przewidywanych skutków dekolonizacji. Przyjmuję widzenie rebelii w kategoriach i pojęciach zaproponowanych przez samego Fanona, równocześnie podkreślając te miejsca w Wyklętym ludzie ziemi, gdzie dyskurs szczególnie czerpie z innych języków i ideologii rewolucyjnych, zwłaszcza z marksistowskiego ujęcia walki klas. Fanon, wychowanek kultury francuskiej, wobec francuskiej rewolucji pozostawał krytyczny, podkreślając, że narzędzia wypracowane przez imperia nie mogą stać się podstawą wyzwolenia spod imperialnej okupacji. Konieczność własnego ujęcia zjawisk rewolucyjnych w oparciu o obserwację rodzących się w Algierii w latach pięćdziesiątych odruchów buntu jest podstawową zasadą omawianego pojmowania rebelii.

Fanon w swoich refleksjach pozostaje jednak blisko historii europejskich rewolucji, o czym świadczyć może przyrównanie używanych przez niego argumentów i definicji do wniosków Crane'a Brintona wysnutych w The Anatomy of Revolution na podstawie komparatystycznego ujęcia owych wielkich przemian (angielskiej rewolucji roku 1640 i jej kontynuacji w 1688, rewolucji amerykańskiej, francuskiej i jej XIX-wiecznych następstw oraz rosyjskiej rewolucji 1917 roku z jej XX-wiecznymi przedłużeniami). Brinton, tak jak Fanon, rysuje zasadniczy szkielet rewolucji, która zaczyna się od 
preliminarnych sygnałów buntu (politycznej i ekonomicznej słabości ${ }^{1}$ ), scalania się grup subwersywnych wobec władzy w jeden (reprezentowany propagandowo) ruch, wytwarzanie ideologicznego podłoża rewolucji przez intelektualistów, zasilających szeregi buntowników, po manifestacje siły wykrystalizowanej grupy, dyktaturę i terror. Definicja rewolucji jako gwałtownej przemiany, przewrotu w uprzednio stabilnych politycznie społeczeństwach, którą wyjściowo przyjmuje Brinton $(1965,4)$, ukazując skomplikowanie narosłej wokół zagadnienia literatury oraz potocznego użycia samego pojęcia, stanowić może w kontekście Fanonowskiego ujęcia dekolonizacji jedynie pewną ogólną ramę modalną. Tę ramę trzeba rozszerzyć o kontekst historii kolonializmu i imperialistycznej ideologii, co jest zadaniem niniejszego szkicu.

\section{Przemoc jako odpowiedź na przemoc}

Punktem wyjścia dla rozważań nad przemianą społeczno-polityczną Algierii jest dla Fanona przyjęcie następującego założenia: nagła zmiana stosunków społecznych wymaga użycia przemocy. Dzieje się tak nie tylko ze względu na gwałtowność procesu dekolonizacji, lecz także na zasadzie odwrócenia, odbicia zastanej rzeczywistości. Przejęte zostają te środki ustanawiania władzy, które zostały wypracowane przez kolonizatora, czyli przede wszystkim siła. Fanon pisze w Wyklętym ludzie ziemi:

Mieszkaniec kolonii, który podejmuje się zrealizować ów [zmiany układów w społeczeństwie] program, być jego siłą napędową, od wieków był przyzwyczajony do przemocy. Od urodzenia zaś nie ma wątpliwości, że ów świat, ciasny i najeżony zakazami, może zostać przebudowany tylko przemocą. $(1985,21)$

1 Co istotne, z historii rewolucji europejskich wynika, że dokonywały się w warunkach gospodarczej prosperity, jednak beneficjentami owych wpływów były jedynie wybrane klasy. Kolonialna opresja z perspektywy okupanta również była źródłem siły roboczej i materiałów produkcji. Niesprawiedliwość nierównego podziału dóbr w sytuacji kolonialnej opierała się na poczuciu podrzędności klasowej i rasowej. Ekonomiczne wykluczenie wzmacnia przekonanie, że to polityczne struktury i układy zmniejszają szansę na osiągnięcie dobrobytu. Ekonomiczna i polityczna „słabość” państwa na chwilę przed rewolucją wynika właśnie z połączenia tych dwu argumentów w jedną sieć współzależności, w której układ polityczny potwierdza ekonomiczny wyzysk. Poza potwierdzaniem nędzy określonych grup społecznych władza w państwach w przededniu rewolucji, jak argumentuje Brinton (1965), jest relatywnie osłabiona i nieskuteczna. 
Użycie siły dla uzyskania władzy jest odpowiedzią na przemoc kolonizatora. Co istotne - dla Fanona jest to odpowiedź naturalna, wrodzona, co do której „nie ma wątpliwości”. Zależność jest nieprzypadkowa - Fanon widzi dekolonizację jako gwałtowną rewolucję społeczeństwa, unieważnienie procesu wspinania się po drabinie społecznej poprzez gest odwrócenia, wejścia na sam szczyt. Wejście to automatycznie powoduje także ruch o odwrotnym kierunku - odebranie władzy kolonizatorowi i zyskanie jego statusu. Dwie odrębne rzeczywistości - kolonizatora i skolonizowanego - w perspektywie rewolucyjnej nie mogą się uzgodnić i współistnieć, ponieważ celem każdego z podmiotów jest sprawowanie władzy.

Dualistyczne terytorium kolonii Fanon konceptualizuje jako „podzielony świat”, dwudzielną, niekoherentną przestrzeń wymuszonej koegzystencji skolonizowanego i kolonizatora. Linię podziału rzeczywistości wyznacza różnica rasowa. Dwa obszary, które wykreśla, to zupełnie różne światy ${ }^{2}$. Miasto, w którym żyje kolonizator jest „z kamienia i stali”, „pełne światła i asfaltu oraz - śmietników pękających od resztek”, „stopy kolonizatora zawsze są osłonięte”, „ulice są czyste, gładkie”, to miasto „syte, leniwe”. W Fanonowskim opisie przestrzeni postrzeganej z punktu widzenia kolonizatora na plan pierwszy wysuwają się wrażenia porządku, dobrobytu i stabilizacji. To samo miasto dla skolonizowanego jest „tubylcze”, „,czarne”, „skulone”, „wygłodniałe, spragnione chleba, mięsa, butów, węgla, światła”, „rezerwat”, to „miejsce podejrzane”, „świat zagęszczony”, „miasto brudasów”. Dominują w tej wizji obrazy stłoczenia, nieporządku, głodu i niebezpieczeństwa.

Manichejską przestrzeń zajmowaną przez skolonizowanego bardzo często opisuje się także za pomocą animalistycznej, deprymującej ludność natywną, metaforyki. „Mówi się o rozpełzaniu się żółtych, o wyziewach tubylczego miasta, o stadach, zaduchu, rojeniu się, mrowieniu, gestykulacji” (1985, 24). Fanon dociera do wniosku o zwierzęcym opisie rdzennych mieszkańców kolonii od strony doświadczenia języka już w trakcie studiów medycznych w Lyonie. W ciągu kilku lat na około pięciuset przedstawicielach białej rasy (o narodowości francuskiej, niemieckiej, angielskiej i włoskiej) przeprowadził ankietę na temat skojarzeń ze słowem „Negro” (Murzyn). W Czarnej skórze, biatych maskach przedstawia rezultaty badania - w blisko 60\% wszystkich odpowiedzi powtarzane były te same skojarzenia: „biologiczność, seks, silny, sportowiec, mocny, bokser, Joe Louis, Jessie Owens, strzelcy senegalscy,

2 Określenia na nazwanie dwóch przestrzeni miasta kolonialnego przytaczam za Fanonem $(1985,22)$. 
dziki, zwierzęcy, diabeł, grzech” (Fanon 2020, 186). Postać „Murzyna” jako biologicznego zagrożenia ${ }^{3}$ stanowi według Fanona upostaciowanie lęków odczuwanych przez białych. Dwie płaszczyzny „podzielonego świata” nie mogą zostać uzgodnione lub wzajemnie się uzupełniać, ponieważ - jak podkreśla Fanon - zgodnie z logiką arystotelesowską „o jedną z nich jest za dużo” (1985, 22). Ostatecznie więc „zniszczyć świat kolonialny to znaczy zlikwidować jedną ze stref, pogrzebać ją na zawsze lub wyrzucić poza granice zajmowanego obszaru" $(1985,23)$. Zajęcie miejsca kolonizatora jest jedną z fantazji nieodzownie towarzyszącej skolonizowanemu, a jego symbolicznym znakiem stają się stosunek płciowy z żoną kolonizatora czy siedzenie za jego biurkiem. Likwidacja jednej z przestrzeni „podzielonego świata” wymaga jednak działań rewolucyjnych, których podstawą jest obrócenie przemocy stosowanej dotychczas przez kolonizatora przeciwko niemu.

Kategoria przemocy jest więc w sytuacji powstańczej wartościowana pozytywnie, ponieważ „człowiek - jak pisze Fanon - wyzwala się w trakcie stosowania przemocy i poprzez nią” $(1985,56)$. Zasadnicza wartość przemocy zasadza się na czterech funkcjach, jakie pełni w procesie dekolonizacji (por. 1985, 61-62). Po pierwsze nadaje kształt działaniom ludu. Jest konkretną formą odpowiedzi na sytuację kolonialną, czyli propozycją walki, w którą mogą się włączyć przedstawiciele różnych warstw społecznych. Przemoc wprowadza również pojęcie wspólnej sprawy, czyli wpływa na kształtowanie się nacjonalistycznej świadomości. Kolejna funkcja siły to wyzwalanie skolonizowanej ludności z kompleksu niższości. Działania rewolucyjne udowadniają, że społeczeństwo cechuje odwaga, przez co wzmacnia się poczucie własnej wartości jego członków. Wreszcie przemoc „wynosi cały naród

3 Fanon przywołuje argumenty, którymi umacniano owe przekonania o zagrożeniu, którego źródłem miały być pewne grupy (rasy bądź przedstawiciele pewnej religii). Murzyni według przeprowadzonego badania symbolizują zagrożenie biologiczne, natomiast Żydzi - intelektualne. Żydzi są podejrzani, ponieważ „chcą posiąść bogactwo lub przejąć pozycję zapewniającą władzę". Murzyni zagrażają natomiast męskości, są symbolem witalności, tężyzny fizycznej i seksualności, które denotują siłę (Fanon 2020, 185). Argumenty, które przytoczył Fanon za respondentami przeprowadzonej ankiety, mogą być widziane jako powtórzenie antysemickich i rasistowskich przekonań, których podstawą była nazistowska ideologia rasy panów (die Herrenrasse, das Herrenvolk). Warto jednak zaznaczyć, że - jak przenikliwie zauważa Hannah Arendt - antysemityzm nie jest w prosty sposób wynikiem ideologii hitlerowskiej i wyprowadzonej z owej ideologii polityki. Wiąże się z długotrwałym procesem schyłku państwa i zmianą roli publicznej oraz ze zmniejszaniem się wpływu żydowskich społeczności na narody przy jednoczesnej stabilności ich majątku (por. Arendt 1984, 11-72). 
na piedestał przywódcy" $(1985,62)$. Rozmywają się idee indywidualnej odpowiedzialności i sprawczości, a ponadto podważony zostaje wizerunek wodza jako figury nieodłącznej dla rewolucji. Wymienione funkcje, jakie siła może pełnić według Fanona w sytuacji rewolucyjnej, łączy zasadniczy warunek włączone w powstańczą działalność powinny zostać możliwie wszystkie warstwy społeczne: od zamieszkujących wsie mas chłopskich, przez masy miejskie (w tym lumpenproletariat), po intelektualistów. Rewolucja w idealnej realizacji jawi się jako manifestacja woli ludu ${ }^{4}$. W ramach prorewolucyjnego stanowiska Fanona ocena przemocy i walki narodowowyzwoleńczej zostaje zawieszona lub zrelatywizowana, ponieważ „wolność to cel uświęcający wszystkie środki, łącznie z przemocą" $\left(1985,37^{-3}\right)^{5}$.

4 Stąd nieufność do figur przywódczych w czasie rewolucji. Uosabiają one prywatne interesy, często samego kolonizatora. Nieufność była dostrzegana przez Fanona także na innych poziomach kontaktu różnych warstw społecznych, zwłaszcza w ramach dwóch relacji: intelektualista-nieintelektualista oraz masy wiejskie - masy chłopskie. Nieufność nieintelektualistów względem intelektualistów jest charakterystyczna dla obszarów mniej gwałtownych walk powstańczych i wynika z powielania wzorców kolonialnych w sytuacji niezależności przez intelektualistów, współpracujących z byłym kolonializatorem i dążących do wzbogacenia się. Fanon pisze, że intelektualiści „zachowują w nienaruszonym stanie reakcje i sposób myślenia nabyte w czasie obcowania z burżuazją kolonialną”. Dalej stwierdza: „rozpieszczani wczoraj przez kolonializm, dziś - przez władzę państwową biorą się do grabienia kraju” $(1985,29)$. Wzbudzanie nieufności mas wiejskich do miejskich jest działaniem zarządców kolonii, którzy chcą utrzymać swoją władzę i celowo kierują uwagę chłopstwa na wartość tradycji, religijnych obrzędów, odwracając ją tym samym od zagadnień narodowych i pozbawiając sił rewolucyjnych znacznego ilościowego potencjału. Masy chłopskie, które w rewolucjach europejskich często stanowiły rodzaj hamulca, według Fanona w powstaniach narodowowyzwoleńczych krajów afrykańskich muszą zostać zaktywizowane i upolitycznione.

5 Problem manifestowania przemocy w imię rewolucyjnego dobra, nawet jeśli uważana jest za nieuniknioną i sprawiedliwą, zajmuje istotne miejsce w rozważaniach filozofów. Emmanuel Lévinas kwestionuje przemoc jako wartość samą w sobie. Twierdzi, że rewolucji gwałtownej powinno się przeciwstawić siłę cierpliwości, dającej możliwość „prawdziwej” zmiany. Lévinas dodaje też, że „ręka, która zaciska się na broni, musi cierpieć z powodu przemocy zawartej w samym tym geście”. „Brak wrażliwości na ten ból - jak przekonuje filozof sprowadza rewolucjonistę na skraj faszyzmu" (Lévinas 1991, 164). Wyprowadzona z religijnych przesłanek postawa oczekiwania, cierpliwości w obliczu cierpienia nie uzgadnia się ze stanowiskiem Fanona, który przemoc traktuje jako wartość, a nawet więcej - jako jedyną adekwatną odpowiedź na mechanizmy władzy kolonialnej, opartej na krzywdzie podległej ludności. 


\section{Od klimatu przemocy do przemocy konkretnej. Przebieg rewolucji}

Pytanie, na które Fanon poszukuje w Wyklętym ludzie ziemi odpowiedzi, brzmi: „kiedy można powiedzieć, że nadeszła pora rozpoczęcia walki wyzwoleńczej” (36). Celem wskazania początku rewolucji, czyli odnalezienia momentu, w którym gesty oporu i sprzeciwu przeobrażają się w radykalny i otwarty bunt wobec zastanej sytuacji, w omawianym przykładzie jest diagnoza kondycji kolonialnej i sposobów jej przekroczenia. Algierski filozof swoją analizę społeczeństwa w przededniu rewolucji uzupełnia o konteksty polityczne, ekonomiczne i kulturowe. Odnosi się do własnego doświadczenia wyniesionego z historii dekolonizacji Algierii i ruchów emancypacyjnych krajów afrykańskich oraz obserwacji poczynionych w trakcie praktyki psychiatrycznej. Fanon zmarł zanim Algieria odzyskała niepodległość od Francji w 1962 roku, jednak był świadkiem i uczestnikiem najważniejszych wydarzeń prowadzących do tego momentu.

Fanonowską koncepcję dziejów rewolucji można objaśnić wyróżniając kilka etapów: od pierwszych symptomów wyzwoleńczego impulsu, które tworzą charakterystyczne zjawisko „klimatu przemocy”, przez negocjacje z władzą kolonialną, etap walki zbrojnej (stanowiący manifestację „przemocy konkretnej”), aż po moment dojrzewania rewolucji, wynikający z nabycia politycznej świadomości przez walczący lud. Posługuję się hasłami „klimatu przemocy” i „przemocy konkretnej” za historiozoficznym pytaniem Fanona: "Jak dokonuje się przejście od klimatu przemocy do przemocy konkretnej? Co powoduje wybuch?" (45).

Początkom walki wyzwoleńczej towarzyszą według Fanona niesprecyzowane przeczucia, że coś się zaczyna i konkretne sygnały ze strony przyszłych rewolucjonistów, jak i reakcje kolonizatora. Jednym z wyraźnych symboli zaczątków buntu jest spontaniczne wyznaczanie „bohaterów” rewolucji, którymi najczęściej zostają „,bandyta całymi tygodniami wymykający się policji, człowiek, który zanim padł, zastrzelił kilku policjantów, więzień popełniający samobójstwo, żeby nie wydać wspólników” (1985, 44). „Klimat przemocy" narasta ponadto w miarę pojawienia się pojęcia narodu w świadomości i powtarzania go jako hasła w trakcie manifestacji, co nadaje działaniom rewolucyjnym jednolitą postać. Przekazy informacji i pogłoski, niezależnymi od władzy kanałami, docierają do uszu buntowników: walka trwa, przenosi się do coraz to nowych miejsc, przemoc jest wszechobecna. Kolonizatorzy obawiają się rewolucji i jej krwawego oblicza, panika wyzwala dwie 
podstawowe reakcje: pragnienie odzyskania kontroli nad sytuacją i jak najszybszego zdekolonizowania państwa, bądź też brutalne i mające zniechęcić rebeliantów represje, które - wbrew przewidywaniom - wzbudzają jeszcze większą przemoc i stanowią „niezwrotny” punkt rewolucji $(1985,59)$. To zakrojone na szeroką skalę represje są według Fanona momentem, który uspójnia działania powstańcze i decyduje o przejściu od „klimatu przemocy” do „przemocy konkretnej”.

Rewolucja nie przebiega podług jednego schematu, jednak, opierając się na doświadczeniach wyniesionych z Frontu Wyzwolenia Narodowego, Fanon wyznacza kilka wydarzeń, które następują po wybuchu walk powstańczych. Pierwszy z nich stanowią negocjacje z władzą kolonialną. Jedna z partii politycznych zostaje wybrana, aby ustalić warunki dekolonizacji narzucane przez kolonizatora - w negocjacjach pomijane są kwestie repatriacji, czy uczciwych warunków wymiany towarów. Najczęściej na wybraną partię składają się inteligenci, którzy ignorują roszczenia i warunki bytowe mas wiejskich oraz umacniają centralną pozycję stolicy. Partie wykluczone z dyskusji przechodzą do działalności nielegalnej i zaczynają rozmawiać z chłopami, szukają wspólnego języka. Dochodzą do wniosku, że „masy wiejskie swe wyzwolenie widziały zawsze w kategoriach gwałtu i przemocy: odbieranie ziemi obcym, walka narodowa, zbrojne powstanie" $(1985,86)$. Działacze uświadamiają lud politycznie i przygotowują go do walki, zbrojne powstanie wybucha bardzo szybko - w interiorze siłę rewolucyjną stanowią chłopi, w miastach lumpenproletariat, czyli „banda głodomorów bez przynależności i miejsca na ziemi” $(1985,87)$.

Rytm walki zbrojnej można scharakteryzować jako cykl narastania i osłabiania się ruchu powstańczego. Rebelia rozpoczyna się gwałtownie: od euforii i upojenia poczuciem solidaryzacji odizolowanych zwykle od siebie warstw społecznych. Reakcja kolonizatora sprowadza się do działań ofensywnych, odpowiadania przemocą na przemoc, co załamuje optymizm pierwszych dni rewolucji i chaotycznych, spontanicznie przeprowadzanych walk i manifestacji. Następuje potrzeba konsolidacji pola, zwykle rozumiana jako ustalenie silnego przywództwa, którego zadaniem jest według Fanona uświadamianie walczących, co do celu, sposobu i możliwości działań powstańczych:

Przywódcy muszą zanegować sens rewolty rozumianej wyłącznie jako bunt i przekształcić ją w rewolucyjną walkę. [...] Opierając się wyłącznie na nienawiści mas, można wytrwać kilka dni, kilka miesięcy, ale nie można zwy- 
ciężyć w wojnie narodowej, nie można zdruzgotać machiny wojennej przeciwnika, nie można zmienić ludzi, jeżeli zaniedba się świadomość bojowników wolność. Nie wystarczy ani granicząca z szaleństwem odwaga, ani najpiękniejsze slogany. $(1985,92)$

Konsolidacji działań rewolucyjnych towarzyszy zaostrzenie środków represji i poszerzenie przez kolonizatora repertuaru walki o działania psychologiczne, np. podjudzanie zwaśnionych plemion do rywalizacji między sobą (koncentrują się oni na mikrokonfliktach zamiast włączyć się w ruch wyzwoleńczy), nawoływanie chłopstwa ustami szamanów i wodzów do powtórnego dowartościowania tradycji, skupienie się na religijności i pojęciu małej zbiorowości zamiast narodu oraz manipulowanie lumpenproletariuszami, którzy stają się najemnikami u boku władzy kolonialnej (1985, 92-93). To moment krytyczny powstania - jego sukces zależy od tej chwili od działań na rzecz upolitycznienia mas. Dojrzałość rewolucji opiera się na upolitycznieniu dokonanym: na umiejętności wyciągania wniosków z błędów, relatywizacji wizerunku kolonialisty (nie reaguje się na każdego nienawistnie i pragnąc jego śmierci) oraz opieraniu projektu tożsamościowego mieszkańców postkolonii o kategorie wykraczające poza ideę murzyńskości czy arabskości.

\section{Diagnoza zagrożeń w postkolonii i próba wyjścia z impasu}

Fanon uzupełnia rekonstrukcję przebiegu rewolucji o diagnozę zagrożeń, z jakimi musi się zmierzyć nowo utworzone państwo. Pierwszym z nich jest przejmowanie wzorców, przeciw którym występowali rewolucjoniści. Właściciele ziemscy przeobrażają się po dekolonizacji w nową burżuazję i nie dążą do zreformowania gospodarki, a zwłaszcza zintegrowania z narodową własnością, a do prywatyzacji i maksymalizowania własnych korzyści. Gospodarka narodowa typu neokolonialnego prowadzi do wyzysku robotników to element znany byłym koloniom - oraz sankcjonuje wyzysk prawnie. Stanowiska kolonizatorów zostają na nowo obsadzone, a więc nie dochodzi do realnej zmiany władzy i poprawienia się warunków życia. Kapitalistyczne uwarunkowania rynkowe nie przystają, jak przekonuje Fanon, do potrzeb państw wypracowujących niezależną pozycję:

Wiemy jednak z pewnością, że ustrój kapitalistyczny nie jest w stanie zapewnić nam warunków realizacji naszego zadania narodowego i naszej 
uniwersalnej misji. Wyzysk kapitalistyczny, trusty i monopole są wrogami krajów słabo rozwiniętych. Ustrój socjalistyczny natomiast, ustrój obejmujący naród jako całość, przyjmujący jako zasadę, że człowiek jest dobrem najcenniejszym, pozwoli nam posuwać się naprzód szybciej i bardziej harmonijnie, unicestwiając tę karykaturę społeczeństwa, gdzie środki produkcji należą do niewielkiej grupy ludzi, a naród w ogóle się nie liczy. $(1985,66)$

Chociaż algierski ideolog stanowczo podkreśla, że podstawą formowania dojrzałej i efektywnej struktury gospodarki krajów tzw. Trzeciego Świata nie może być wybór między kapitalizmem i socjalizmem, a wypracowanie własnej struktury (po rozpoznaniu bogactw naturalnych ziem, przeorganizowaniu eksportu towarów i kontroli kanałów wymiany międzynarodowej, rozszerzeniu rynku zbytu), wyraźnie wskazuje na podstawy ideologiczne socjalizmu jako bliższe potrzebom gospodarczym byłych kolonii. Ideałem rozwoju wyzwolonego państwa byłoby dla Fanona pominięcie etapu państwa burżuazyjnego - tym twierdzeniem oddala się od marksistowskiego ujęcia rewolucji socjalistycznej. Zasadniczo jednak Fanon pragnie dokonać cięcia między ruchem powstańczym w Algierii a europejskimi wcieleniami ideologii i samej praktyki (historii) przewrotów. Zarówno ideologia, jak i sama praktyka działania nie przystają bowiem jego zdaniem do potrzeb wyzwalającej się kolonii. Skoro sam potencjał owego sprzeciwu opiera się na zasadniczym odrzuceniu tradycji imperialistycznej, nie może sięgać po środki buntu wypracowane w ramach owego systemu. W samym buncie istniałaby bowiem nierozstrzygalna sprzeczność, potęgująca jeszcze heglowską zasadę antytetycznego rozwoju nowego porządku, który wyłaniać się musi z negacji zastanej rzeczywistości (a więc i uznania owej rzeczywistości). Rewolucja poza buntem wymierzonym przeciw kolonializmowi zyskuje dodatkowy wymiar - walki klasowej ${ }^{6}$.

6 Koncepcja rewolucji Fanona wykazuje dużą łączliwość z myślą marksistowską - nie tylko w zakresie słownika, lecz także konkretnych diagnoz społeczeństwa. Jedną z podstawowych cech łączących Fanona z pismami Marksa jest przekonanie, że dojrzała świadomość klasowa stanowi glebę rewolucji (por. Wheen 2007,18 ) oraz wywodzenie rewolucji politycznej z uprzedniej rewolucji ekonomicznej. Harry Cleaver w Politycznym czytaniu „Kapitatu” podkreśla z kolei, że pojęcie świadomości klasowej jest w interesie organizacji, związków, partii itd., a nie rewolucyjnego ruchu robotniczego: „rozprzestrzenianie się buntu, kiedy różne sektory łączą się ze sobą, wzajemnie uzupełniając, sprawia, że klasa naprawdę jednoczy się przeciwko kapitałowi. Gdy brak tej komplementarności »świadomość klasowa « na nic się nie zdaje, a gdy takowa istnieje, »świadomość klasowa « staje się zbyteczna” (Cleaver 2011, 82). 
Kolejnym zagrożeniem dla niepodległych krajów jest walka z wynaturzonymi następstwami zjawisk, które na etapie walki wyzwoleńczej były pożądane i konieczne, czyli ultranacjonalizmem, szowinizmem i rasizmem (1985, 106-112). Znaczenie powtarzanego hasła ,jedność afrykańska” staje się mgliste, mimo to wszechobecne są postulaty negryfikacji i arabizacji kadr i kultury, obcokrajowcy są widziani jako zagrożenie, element nieznany i niechciany, odtwarzane są przedkolonialne formy kultury i religii - historia opresji kolonialnej zostaje wyparta, zanim została należycie przepracowana. Prowadzi to ostatecznie do znieruchomienia kultury i nieproduktywności, jest przedłużeniem generalizacji czynionych uprzednio przez kolonizatora (przejęciem uniwersalnych struktur, w ramach których wszyscy czarnoskórzy są tacy sami), odrywa społeczeństwo i jego wytwory od aktualności oraz przenosi w rzeczywistość stale zapośredniczającą się w historii.

Groźba dyktatury - jako naturalnej konsekwencji ustania rewolucji jest zagrożeniem, które Fanon poddaje krytycznemu namysłowi ${ }^{7}$ Partiom

Fanon nie przejmuje jednak Marksowskiej myśli w całości - postuluje m.in. ominięcie fazy burżuazyjnej w rozwoju państwa socjalistycznego po przeprowadzonej rewolucji, negując równocześnie myśl Marksa, który, odpowiadając rosyjskim narodnikom, zauważa, że niemożliwa jest rewolucja bez etapu ustroju kapitalistycznego (Cleaver 2011, 91). Fanonowskie rozważania o kolonializmie i konieczności wyzwolenia można też rozpatrywać w kontekście tzw. teologii wyzwolenia (wywodzonej z pism samego Marksa: W kwestii żydowskiej [1960] Przyczynek do krytyki heglowskiej filozofii prawa [1960]).

7 Używając podobnych do Fanona argumentów krytycznie wobec schedy Rewolucji Październikowej wyrażał się Lew Trocki. W napisanej w 1936 roku Zdradzonej rewolucji. Czym jest ZSRR i dokąd zmierza? komentował zagrożenia systemu w związku z wytworzeniem biurokracji i przewidywał konieczność powtórnego nastania rewolucji. Trocki w jedenastym rozdziale składającym się na gorzką krytykę polityki ZSRR konstatuje: „Chodzi nie o to, żeby jedną klikę rządzącą zamienić na inną, ale o to, żeby zmienić same metody zarządzania gospodarką i kierowania kulturą. Biurokratyczny absolutyzm musi ustąpić miejsca demokracji radzieckiej. Przywrócenie prawa do krytyki i rzeczywistej swobody wyborów jest niezbędnym warunkiem dalszego rozwoju kraju. Wymaga to przywrócenia swobody partii radzieckich, poczynając od bolszewików, i odrodzenia związków zawodowych. Przeniesienia na gospodarkę demokracja oznacza radykalną rewizję planów w interesie ludzi pracy. Swobodna dyskusja nad problemami gospodarczymi obniży wydatki uboczne z tytułu biurokratycznych błędów i meandrów. Kosztowne zabawki - pałace rad, nowe teatry, pokazowe metro - ustąpią miejsca mieszkaniom dla robotników. »Burżuazyjne normy dystrybucji « zostaną wtłoczone w granice ścisłej konieczności, żeby w miarę wzrostu dobrobytu społeczeństwa ustąpić miejsca równości socjalistycznej. Rangi zostaną natychmiast zniesione, błyskotki do zawieszania na piersi jako ordery wrzucone do tygla. Młodzież będzie mogła swobodnie oddychać, krytykować, popełniać błędy i dojrzewać. Nauka i sztuka wyzwolą się z okowów. Wreszcie, polityka zagraniczna powróci do tradycji internacjonalizmu 
politycznym po okresie dekolonizacji nierzadko towarzyszy przekonanie, że dyktatura jest potrzebna dla rozwoju społeczeństwa: „bardzo często skłonni do uproszczeń przedstawiciele młodej burżuazji utrzymują, że w kraju rozwijającym się konieczne są rządy silnej ręki lub dyktatura" $(1985,124)$. Przywódca najczęściej ma przeszłość wojskową i jest zasłużonym bohaterem rewolucji, stąd cieszy się zaufaniem ludności zjednoczonej wokół sprawy narodowej. Dyktator staje się jednak fasadowym symbolem, który ma za zadanie uspokajać lud i utrzymywać bezwzględny porządek i posłuszeństwo mas, postrzeganych przez partie jako zagrożenie. Jego bohaterskie czyny z czasów wyzwoleńczej walki wzbudzają zaufanie ludu, który zostaje odizolowany od władzy i przestaje zyskiwać świadomość historyczną i polityczną. Po upływie czasu - kiedy sytuacja się nie poprawia - masy zaczynają kwestionować przywództwo dyktatora i jego skuteczność, jednak ustanowione przez partię struktury organizacyjne (służby porządku publicznego, wojskowe) trzymają niezadowolone społeczeństwo w ryzach.

Fanon przekonuje, że zamiast reżimu kraje rozwijające się potrzebują demokratycznych partii politycznych, które rozumie w szczególny sposób - jako: narzędzie w rękach ludu i zdecentralizowany organ. Postulat służby dla ludu ma się realizować poprzez szereg zachowań. Po pierwsze przez używanie języka zrozumiałego dla mas, za którym nie kryją się prywatne interesy grabieżcze. „Wraz z możliwością zrozumienia - podkreśla Fanon - odbiera się ludowi jego własność i suwerenność” $(1985,129)$. Ponadto duży nacisk kładzie na edukację ludu, jego kształcenie do pracy traktowanej w kategoriach przyjemności i edukację upolityczniania, która jest rozumiana jako zyskiwanie pogłębionej i intelektualnej świadomości sensu zbiorowych działań, $\mathrm{w}$ tym podejmowania pracy (por. 1985, 131-137). Kategoria pracy zajmuje ważne miejsce w Fanonowskim wywodzie, ponieważ musi zostać odseparowana od narosłych w okresie kolonialnym kontekstów: przede wszystkim wyzysku, przemocy (kary cielesne, przykładowe egzekucje) oraz braku indywidualnej korzyści z wykonywanej pracy. Fanon problematyzuje trudności, jakie napotyka władza u początku prywatyzacji postkolonii: powtarzanie wzorców organizacji pracy opartych na wyzysku ${ }^{8}$. Po trzecie służba dla

rewolucyjnego" (Trocki, 1991). Fanon podobnie jak Trocki zauważa więc ryzyko związane z odchodzeniem od demokracji na rzecz autorytarnych rządów.

8 Zrekonstruuję przykład podany przez Fanona na wyjaśnienie trudności z wypracowaniem dojrzałego pojęcia pracy jako wartości. W latach 1956-1957 francuskie władze utrudniły ruch ludności, co właściwie uniemożliwiło właścicielom sklepów spożywczych dojazd do miast $\mathrm{w}$ celu zaopatrzenia się $\mathrm{w}$ potrzebne produkty. Ceny zaczęły więc rosnąć, oprócz 
ludu ma zmobilizować do pracy i współtworzenia nowego narodu całe społeczeństwo, w tym kobiety, które należy traktować na równi z mężczyznami, odchodząc od feudalnych i patriarchalnych tradycji $(1985,138)$. Ostatni postulat polega na jak najszybszym osłabieniu haseł narodowych przez partie i zastąpieniu ich kwestiami istotniejszymi dla sytuacji życia codziennego:

Walka z głodem, ciemnotą, nędzą, zacofaniem musi stać się stałym elementem rzeczywistości krajów postkolonialnych. Praca, wola przezwyciężenia wszystkiego, co na wieki wygnało lud z historii ludzkiej myśli, powinna nieustannie zaprzątać umysł i mięśnie obywateli. $(1985,139)$

Decentralizacja natomiast miałaby polegać na „zdesakralizowaniu stolicy” $(1985,27)$ i przyznaniu „interiorowi”, czyli pozamiejskim obszarom w głębi kraju, uprzywilejowanej roli. Celem jest uniknięcie migracji mas wiejskich do miast w poszukiwaniu dobrobytu i ich przeistaczania się w lumpenproletariat. Decentralizację można, jak twierdzi Fanon, przeprowadzić na dwa sposoby: przenosząc stolicę do jednego z mniejszych ośrodków, nie uprzywilejowując tym samym kolonialnego centrum oraz stwarzając kierownicze ośrodki regionalne i rozpraszając w ten sposób władzę, co oddala widmo dyktatury zagrażające postkolonii $(1985,127)$.

\section{Oddziaływanie politycznej myśli Fanona}

Wyklęty lud ziemi i Czarna skóra, białe maski są z perspektywy współczesnych badaczy postrzegane jako najpełniejszy wykład politycznej myśli Fanona (Drabinski 2019). Wśród komentatorów algierskiego filozofa wskazałam już Saida, Bhabhę, Rabakę i Mbembego. To właśnie ten ostatni traktuje spuściznę Fanona jako podstawowy punkt odniesienia we własnej diagnozie współczesnego społeczeństwa odchodzącego od demokracji w stronę nacjonalizacji. Mbembe dzieli się swoim doświadczeniem lekturowym pism Fanona:

tego rozwijał się czarny rynek. Zaczęto nadzorować działalność sprzedawców - towary były dostarczane z hurtowni ze wskazaniem cen, do których sklepikarz mógł naliczyć ustaloną uprzednio marżę. Przedsiębiorca wymyślał więc nowy sposób na większy zysk - ogłaszał, że towar się wyprzedał i przenosił całą działalność na czarny rynek. Władza reagowała w różny sposób: nakładała kary finansowe, zamykała sklepy, bądź je przejmowała, zatrudniając w nich sklepikarzy i wypłacając im pensję. W ten sposób, jak sądzi Fanon, lud uczy się działania podstawowych praw ekonomii, takich jak akumulacja kapitału (por. 1985, 129-130). 
[...] prawie nie sposób wyjść bez szwanku z lektury Frantza Fanona. Trudno czytać go, nie czując się wezwanym przez jego głos, jego słowo, jego rytm, jego język, jego dźwięki i brzmienia, jego spazmy, skurcze, jego oddech. (Mbembe 2018, 199)

Stanowisko Mbembego jest istotne zwłaszcza dlatego, że diagnozuje on zagrożenia wpisane w Fanonowską koncepcję przemocy i daleko idące konsekwencje wynikające z absolutyzowania wartości rewolucyjnie wyrażanego buntu. Kameruński filozof przyznaje, że dekolonizacja nie mogła się odbyć bez przemocy, jeśli miała w istocie doprowadzić do wyrażenia siebie w ruchu sprzęgniętym z kolonialną siłą. Niemniej jednak konstatuje: „czysta i nieograniczona przemoc, jakkolwiek twórcza, mogła stać się ślepa. Uwięziona w jałowej powtarzalności, mogła w każdej chwili zwyrodnieć, a jej energia zostać zaprzęgnięta w służbę destrukcji dla samej destrukcji” (Mbembe 2018, 16). Mbembe sygnalizuje możliwość wyczerpania siłowej manifestacji woli i jej niekonstutywnego charakteru we współczesnych konfliktach. Anarchizm zagraża według filozofa nie tylko przeciwnikom rebelii, lecz także samym buntownikom, przeciwko którym może się zwrócić przemoc.

Budowanie zarówno tożsamości wspólnotowej, jak i programu rewolucyjnego jedynie na kategoriach nienawiści jest skazane na porażkę, czego świadom był sam Fanon. Wielokrotnie w swoim wykładzie podkreślał, że bunt musi dojrzeć, aby zakończyć się powodzeniem - a dojrzałość osiąga właśnie przez przekroczenie programów opartych na manifestacji siły, wrogości oraz poprzez upolitycznienie mas. Mbembe wyraźnie wskazuje różnicę między Fanonowską kategorią przemocy a anarchistyczną, destrukcyjną siłą w obrębie współczesnych demokracji - jest nią opozycja produktywnośćnieproduktywność. O ile krytykowane przez niego debaty opierają się na wartości przemocy samej w sobie, o tyle w projektach Fanona „każda przemoc ma moc stworzenia czegoś nowego" (Mbembe 2018, 104). Produktywność rewolucji staje się jej usprawiedliwieniem.

Oddziaływanie ideologii Frantza Fanona na nurt badań postkolonialnych wynikało z przystawalności analizy do reinterpretacji w nowych kontekstach społeczno-politycznych. Blake T. Hilton podkreśla, że „analiza Fanona może być użyta do zbadania i zrozumienia innych nacji, które dzielą, dehumanizują i ciemiężą grupy ludzi ze względu na rasę, pochodzenie, religię czy kolor skóry, jak również do zrozumienia psychologicznego wpływu, jakie mają te działania” (2011,50). We własnym wywodzie przykłada kategorie wypracowane przez algierskiego ideologa do sytuacji rdzennych 
mieszkańców Ameryki Północnej. Rozprawa Fanona, w angielskim przekładzie opublikowana pod tytułem Black skin, white masks, zostaje przepisana przez kolejnych badaczy, którzy skupiają się na innych grupach podległych, w książkach: Red Skin, White Masks Glena Coultharda i Brown Skin, White Masks Hamida Dabashiego. Natomiast Shawn O. Utsey, Mark A. Bolden i Andraé L. Brown analizują sytuację Afroamerykanów w Stanach Zjednoczonych w ramach tej samej ramy pojęciowej. We wspólnym wykładzie przedstawiają Fanona jako „proroka rewolucji” (Utsey, Bolden i Brown 2001, 313). Staje się on postacią symboliczną, a jego dorobek wykorzystywany jest w ramach wielu dyskursów - Reiland Rabaka wyróżnił pięć form „fanonizmu”, w których akcentowane są inne zagadnienia wywiedzione z prac algierskiego myśliciela. Są to fanonizmy: antyrasistowski, dekolonialny, marksistowski, feministyczny i rewolucyjnego humanizmu (2011). Żywotność i różnorodność owych form inspiracji myślą Fanona, umocowanych w różnego rodzaju dyskursach, stanowią widomą oznakę wpływu owego myśliciela na pojmowanie procesów rewolucji, emancypacji i wyzwalania się. 


\section{Bibliografia}

Althusser Louis i Étienne Balibar. 1975. Czytanie Kapitału. Tłum. Wiktor Dłuski. Warszawa: Państwowy Instytut Wydawniczy.

Arendt, Hannah. 1984. Źródła totalitaryzmu. Warszawa: Wydawnictwo Zbliżenia.

Brinton, Crane. 1965. The Anatomy of Revolution. New York: Vintage Books. Butler, Judith. 2018. Psychiczne życie władzy. Teorie ujarzmienia. Thum. Tomasz Kaszubski. Warszawa: Wydawnictwo Krytyki Politycznej.

Cleaver, Harry. 2011. Polityczne czytanie Kapitału. Tłum. Iwo Czyż. Poznań: Oficyna Wydawnicza Bractwa „Trojka”.

Coulthard, Glen Sean. 2014. Red Skin, White Masks: Rejecting the Colonial Politics of Recognition. Minneapolis: University of Minnesota Press.

Dabashi, Hamid. 2011. Brown Skin, White Masks. London: Pluto Press.

Drabinski, John. 2019. „Frantz Fanon”. W The Stanford Encyclopedia of Philosophy, ed. spring 2019, red. Edward N. Zalta. 14.03.2019. Dostęp: 13.11.2019.

Fanon, Frantz. 1962. Algieria zrzuca zastonę. Tłum. Zygmunt Szymański. Warszawa: Iskry.

1985. Wyklęty lud ziemi. Tłum. Hanna Tygielska. Warszawa: Państwowy Instytut Wydawniczy.

2020. Czarna skóra, białe maski. Tłum. Urszula Kropiwiec. Kraków: Wydawnictwo Karakter.

Fitzpatrick, Sheila. 2017. Rewolucja rosyjska. Tłum. Jakub Bożek. Warszawa: Wydawnictwo Krytyki Politycznej.

Hilton, Blake T. 2011. „Frantz Fanon and Colonialism: A Psychology of Oppression”. Journal of Scientific Psychology: 45-59.

Lévinas, Emmanuel. 1991. „Cnoty cierpliwości”. Tłum. Agnieszka Kuryś. W Emmanuel Lévinas, Trudna wolność. Eseje o judaizmie, 163-164. Gdynia: Wydawnictwo Atext.

Marks, Karol. 1960. „Przyczynek do krytyki heglowskiej filozofii prawa”. Tłum. Tadeusz Zabłudowski. W Karol Marks i Fryderyk Engels, Dzieła, tom I, red. Tadeusz Zabłudowski, 243-407, Warszawa: Książka i Wiedza. 1960. „W kwestii żydowskiej”. Tłum. nieznany. W Karol Marks i Fryderyk Engels, Dzieta, tom I, red. Eugenia Wolicka, 420-456. Warszawa: Książka i Wiedza.

Mbembe, Achille. 2018. Polityka wrogości. Tłum. Urszula Kropiwiec. Kraków: Wydawnictwo Karakter. 
Poradowski, Michał. 2006. Teologia wyzwolenia Karola Marksa. Wrocław: Wydawnictwo Nortom.

Rabaka, Reiland. 2011. Forms of Fanonism: Frantz Fanon's Critical Theory and the Dialectics of Decolonization. Lanham: Lexington Books.

Rajeev, Patke S. 2001. „Frantz Fanon (1925-1961)”. W Encyclopedia of Postcolonial Studies, red. John C. Hawley i Emmanuel S. Nelson, 162-167. Westport: Greenwood Publishing Group.

Trocki, Lew. 1932. Historja rewolucji rosyjskiej. Tom I. Rewolucja lutowa. Tłum. Stanisław Łukomski. Warszawa: Bibljon. Dostęp: 18.12.2019.

- 1991. Zdradzona rewolucja. Czym jest ZSRR i dokad zmierza?. Tłum. Aleksander Achmatowicz. Warszawa: Oficyna WIBET. Dostęp: 18.12.2019.

Utsey Shawn O., Mark A. Bolden i Andraé L. Brown. 2001. „Visions of Revolution from the Spirit of Frantz Fanon: A Psychology of Liberation for Counseling African Americans Confronting Societal Racism and Oppression”. W Handbook of Multicultural Counseling, wyd. 2, red. Casas Ponterotto i Alexander Suzuki, 311-336. Thousand Oaks: Sage Publications.

Wheen, Francis. 2007. Marks, Kapitat. Biografia. Tłum. Piotr Laskowski. Warszawa: Muza SA.

Zeilig, Leo. 2016. Frantz Fanon: The Militant Philosopher of Third World Revolution. London - New York: I. B. Tauris. 


\title{
Abstract, keywords, about the author
}

\begin{abstract}
From climate of violence to concrete violence. Revolution in Frantz Fanon's philosophy

The article shows the philosophical idea of revolution formulated by Frantz Fanon in relation to the process of decolonization in his work The Wretched of the Earth. The conception of "world divided into compartments" - in which the colonialized territory is seen as a bipartite, incoherent space of forced coexistence of the colonized and the colonizer - is being analysed in detail. Animalistic imagery depressing natives was used for a description of dependent lands and was a way to strengthen the difference and highlight the separateness (not only a cultural one, but also racial and even opposition of human and inhuman/animal). In his prorevolutionary stand Fanon suspended and relativized the evaluation of violence and liberating war. Next subjects of the analysis are violence and threats connected to the forms of resistance and the moment of transition between the first, gentle rebellion strategies to revolutionary movements leading to decolonization. In the last part of the article I outline the impact of Fanon's philosophical conception of revolution.
\end{abstract}

Keywords: colonialism, Frantz Fanon, revolution, decolonisation, violence

Izabela PoręBA, Master of Arts in Polish Philology and in Digital and Network Publishing; PhD candidate at the University in Wrocław. At this point she is working at the doctoral thesis about postcolonial strategies of writing by artists representing Francophone African literature under the supervision of dr hab. prof. UWr Marian Bielecki. Main research interests: cultural theory of literary research, postcolonial theory, modern world literature and philosophy.

E-MAIL: izabela.poreba@uwr.edu.pl 